\title{
Matrix-Remodeling-Associated Protein 5
}

National Cancer Institute

\section{Source}

National Cancer Institute. Matrix-Remodeling-Associated Protein 5. NCI Thesaurus. Code C115379.

Matrix-remodeling-associated protein $5(2828 \mathrm{aa}, \sim 312 \mathrm{kDa})$ is encoded by the human MXRA5 gene. This protein may play a role in remodeling of the extracellular matrix. 